\title{
Assessment-for-Learning Teaching Mode Based on Interactive Teaching Approach in College English
}

\author{
https://doi.org/10.3991/ijet.v15i21.18029
}

\author{
Rui Sun $\left.{ }^{(}\right)$, Huihui Zhang \\ Heze Medical College, Heze, China \\ abc7320938@126.com
}

Jing Li

Heze University, Heze, China

Jing Zhao

Guizhou Education University, Guiyang, China

Peipei Dong

Hebei GEO University, Shijiazhuang, China

\begin{abstract}
English teaching plays an extremely important role in college education. It cannot just improve students' English level, but also help students adapt to the increasingly open and complex society. Besides, it is an important foundation for students to further go to the world and integrate in the world development trend. Although English teaching has received attention of various colleges and universities, there are still many problems in college English teaching, and the teaching effect is not obvious. To make teaching conform to the rapid development of the new education environment and make teaching practice more fitted with the standard of modern education, teaching mode reform for college English is imperative. Based on the teaching idea of "assessment for learning", the teaching management system was designed in this study, including three steps: teaching intelligence system, assessment and test system, and information feedback system. Meanwhile, interactive teaching approach was combined to plan the interactive teaching process of college English course, including the process of proposing and solving questions, independent thinking and cooperative learning module, and leaning achievement exchange activity. In the end, assessment-for-learning teaching mode was used to collect the data of four dimensions (degree of learning engagement, completion degree of English learning content, degree of English learning interaction, and English learning effect) and the learning performance evaluation system supported by big data was established. The experimental results show that the teaching mode in this study could effectively improve students' learning performance and enhance their actual English application ability.
\end{abstract}

Keywords-Interactive teaching approach; assessment for learning; learning performance; English course 


\section{Introduction}

In the modern society, modern scientific and technological information increases rapidly. The growth rate of knowledge becomes faster and faster, and the skill update time becomes shorter and shorter. The amount of scientific knowledge accumulated by human beings in recent 30 years has accounted for $90 \%$ of total amount of scientific knowledge, while the amount of scientific knowledge accumulated in the past thousands of years only accounted for 10\% [1]. Beyond all question, actual situations such as massive information, technical diversity and approach complexity bring the question "how to learn" to learners. As a part of college education and teaching system, English is one of the most important teaching contents in various colleges and universities, and it is always an important course that schools cannot ignored [2]. Therefore, the discipline orientation of English teaching means educators must keep optimizing teaching methods and carry out scientific teaching reform and exploration.

At present, as the big data of internet technology comes, schools utilize all kinds of online teaching platforms to implement individualized online teaching for students. College English course is no exception. However, the survey shows that there are some defects in online English teaching. For example, individuation of online teaching cannot be fully embodied, and students' satisfaction for online English teaching platform is not high. In addition, teachers' teaching mode fails to form a complete system. There is lack of interaction with students in the teaching process, which affects students' learning initiative. Even some bad learning habits such as absence from class and English class assignments in arrear appear. In the meantime, most English teachers still follow traditional teaching method which not merely lacks the cultivation of English application ability, but also excessively lays particular stress on the content of teaching materials and lacks expertise of college English [3].

In conclusion, College English was chosen as the main teaching content in this study to investigate the reform method of online English teaching. Moreover, the teaching thought of "assessment for learning" was creatively proposed. Interactive learning was advocated in teaching to constitute an effective combination of online English teaching and classroom English teaching and to form assessment-for-learning teaching mode in college English based on the interactive teaching approach. The aim of this study was to explore a method to improve teaching efficiency for language courses and cultivate more qualified language talents conforming to social requirements.

\section{State of the Art}

Under the general background of economic globalization and world integration, language application and communication are undoubtedly influenced greatly. As international communication becomes increasingly frequent, foreign languages receive more and more attention of more countries. Many countries input large quantities of manpower, material resources and financial resources to support the 
development of foreign language teaching. Currently, many scholars have discussed the drawbacks of traditional teaching mode in college English and put forward many course mode reform schemes. All these have greatly promoted the change of college English teaching mode. Western countries took the lead in proposing diversified advanced and scientific foreign language teaching methods because of their social and economic advancement. Developed countries abbreviate "English as a Second Language" as ESL, and the course is one of important courses in English education field [4]. The teaching methods differ according to the classification of English learners. The first category mostly refers to generalized immigrants; the second category refers to international students to be enrolled into local schools; the third category refers to local citizens whose family language is not English. "English as a Second Language" course (hereinafter referred to as "ESL" course) is provided for the learners whose native language is not English, and English they learn is actually their second language. Another English teaching course in developed countries is ESOL (English to Speakers of Other Languages) course [5]. The difference between the two mainly lies in the natural environment of English study. The course that is learned in an English-speaking environment is ESL course, while the course that is learned in a non-English-speaking environment is ESOL course. Glendale Community College [6] introduced social service-learning items in English class, and the teachers paid special attention to introducing local actual life in class or extending the class to more liferelated aspects. It was found that such teaching mode contributed to improving students' language application ability. Hagan et al. [7] firstly carried out psychological assessment for students in English teaching, and provided international student of psychology with a series of language learning assistance for ESL course, including targeted tutoring. The students in the University of Texas were often required to give lectures or presentations in language study. Students expressed their opinions according to the themes, gave a lesion, debated a question among students or discussed a social issue. Such teaching mode is more beneficial to improve students' language understanding, thus enhancing English expression capacity. Muhanna et al. [8] applied online games in English vocabulary teaching of students in the University of Jordan. The team designed a pre-/post-test to measure students' English vocabulary proficiency. The results showed that, the English vocabulary of the experimental group improved significantly. Gimenez et al. [9] reported the experience of English teaching practice in "Letras" course. The teacher and students were responsible for designing and implementing the course content provided on Moodle platform. Besides, introspection and cooperative teaching method were used, and the result showed that such distance teaching could overall cultivate students' English learning ability.

With rapid development of modern science and technology, educators are continuously exploring rational English teaching methods and applying new media technology for language teaching. For the problems of educator teaching activity design and low student participation in college English class, Sun [10] came up with a new interactive teaching mode which contributed to motivating students' learning interest and could help students construct an English course English course. Sun [11] put forward a teaching mode based on SPOC + Rain Classroom and applied such 
teaching mode in college English teaching process. It was found that such new teaching mode could effectively improve students' learning initiative and it was also a new thought of reforming traditional college English course. Ling et al. [12] designed a deep learning method based on SPOC (Small Private Online Courses). The method referred to the superior online teaching resources of SPOC. Without time and place limit, it attracted learners' learning interest, broke the limitations of traditional classroom stressing memory and preliminary understanding, and emphasized teacher's differential teaching and students' autonomous learning. The experimental results showed that such teaching method could enhance the interaction between teachers and students, and greatly improved teaching quality of college English. In conclusion, the ultimate goal of college English teaching is to let students communicate in English after they enter the society. Except making students learn knowledge in a more targeted way, college English also should cultivate students' autonomous learning ability and innovation capacity so as to lay a foundation for future work. However, at this stage, some problems still exist in English teaching, like low learning interest and relative lack of English teaching team. Many schools implement "large class" teaching method, and it is difficult for the teacher to understand learning situation of every student. At the same time, in the face of uneven English level, it is also hard for the teacher to vary with each individual in classroom teaching, thus leading to students' weak enthusiasm, initiative and creativity.

On this basis, "assessment-for-learning" teaching method was creatively proposed in this study. "Assessment for learning" is an evaluation method. Although there are many studies on teaching evaluation, it is difficult for the evaluation to promote learning due to the deep impacts of examination culture, and the problems of low efficiency and poor effect still exist. Hence, "assessment for learning" is an evaluation method with the primary goal of facilitating students' learning. Meanwhile, the interactive teaching approach was employed in this study, and a learning performance evaluation system suitable for the course mode was constructed. The purpose was to understand students' English knowledge and level in advance, analyze characteristics of students with poor English knowledge and pay more attention to those with poor performance and weak knowledge level in the early stage of English course. The author hopes this teaching mode could make up for the deficiency of previous English teaching and provide an objective reference for language teaching reform.

\section{Interactive Teaching Approach in Assessment-for-Learning Teaching Design for College English}

\subsection{Application of interactive teaching approach in assessment-for-learning teaching}

The interactive teaching mode [13] is student-centered two-way interaction between teachers and students, which can fully mobilize dynamic mechanism of students and teachers and stimulate the thirst for knowledge. But it also tests learning initiative, enthusiasm and creativity of teachers and students. Hence, teachers are 
required to actively change traditional teaching mode, guide students in class, let student's enthusiasm their independent thinking ability in a self-oriented way, make them find weak steps in English learning, actively solve and think problems, and finally evaluate students' learning process. Nevertheless, teachers should fully understand knowledge points that students easily misunderstand according to the statistics of online big data, and design the interaction questions on the basis. For these difficult points, students usually generate wrong understanding. If students can interact and discuss on these questions, their thirst for knowledge can be more easily stimulated and they can motivate creativity of teachers and students with democratic, open and equal mentality. We designed the interactive teaching process of college English course which not merely covers the problem of proposing and solving questions, but also includes independent thinking and cooperative learning. Finally, students exchange about learning achievements. Moreover, the interactive teaching mode of college English also underlines the acquisition of internet information data, supply of instant communication platform, online teaching intelligent and flexibility. The pre-class step includes application of network resources to arrange pre-class preview exercise, and online interaction for the questions in the exercise. In class, the teacher explains questions in pre-class preview and encourages students to solve problems by utilizing big data of network platform. Meanwhile, students can cooperate for investigation, finally show the research results of each team and give feedback and evaluation of teacher's teaching level.

In the teaching process of college English teaching, the interaction between students and teachers and learning performance were evaluated. The data of four dimensions (degree of English learning engagement, completion degree of English learning content, degree of English learning interaction, and English learning effect) were collected through the college English teaching assistance platform of online interactive teaching method based on assessment for learning, and the learning performance evaluation system supported by big data was established. In the class of college English, students' learning process and teacher's teaching process could be assessed and judged rationally, and the feedback information could be provided for teachers in time so that teachers could intervene in students in time, adjust learning attitude and promote learning method improvement. The specific process is shown in Fig.1. 


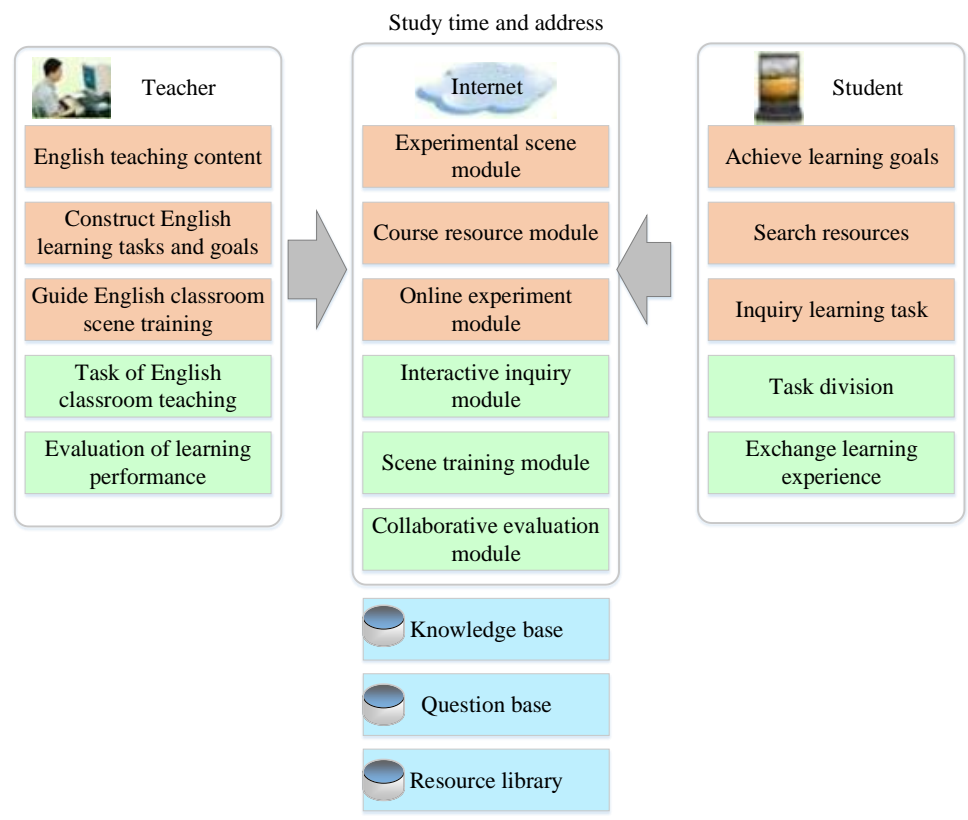

Fig. 1. Construction diagram of interactive teaching mode for college English

\subsection{Application of college English teaching case library in assessment-for- learning teaching}

College English course should help students establish practical awareness of spoken English and English reading awareness based on the knowledge points of College English course. The case library technology means the teacher sets a teaching case according to the content of teaching material in English teaching. In the traditional case teaching, the teacher gives examples and explanation according to the cases and textbook. In the case teaching under this teaching mode, the teacher selected a teaching task in the "case database" according to the new knowledge point and students independently completed it. In this study, the case library of college English course is in the new teaching mode, and the teaching design follows the teaching principle of "one three two", as shown in Fig.2. "One three two" teaching framework includes the following: "one" refers to the training objective: regard English learning ability training as the objective; "three" refers to ability cultivation: cultivate students' ability to discover, analyze and solve problems in college English course; "two" refers to teaching objective: the teaching objective of this course is to enhance students' practice consciousness and learning consciousness. Through the teaching and learning integration in English course, the training of English learning training can be enhanced to improve students' English performance. 


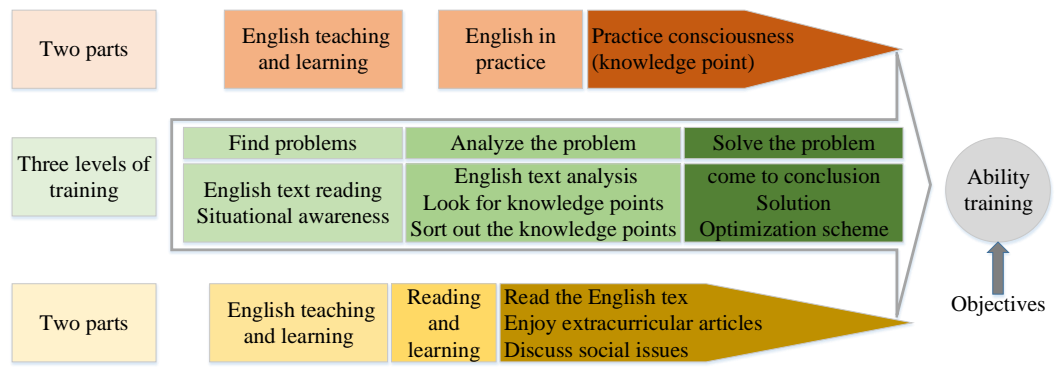

Fig. 2. College English case library teaching design diagram based on assessment for learning

As shown in Fig.2, training ability is reflected in three-level training in the teaching mode. The ability to discover problems mainly focuses on guiding students to read English texts independently and find out problems in learning, such as incomprehension of English clause meaning in the text and incognizance of an English word. With regard to the ability to analyze problems, the teacher assigns learning tasks, and guides students to analyze English text according to the tasks, look for the knowledge points and summarize new knowledge points. In the whole process, students independently complete the tasks to enhance their English problem analysis ability. The ability to solve problems is the last teaching step in the process. The teacher gives correct summarization according to students' completion degree. According to the problems that most students are difficult to complete, the teacher gives the correct solution, and encourages students to further optimize on the basis of teacher's solution, thus improving students' English problem-solving ability. Figs.3-5 show PowerPoint presentation independently completed by students according to teacher's case questions in the college English case library teaching based on assessment for learning.

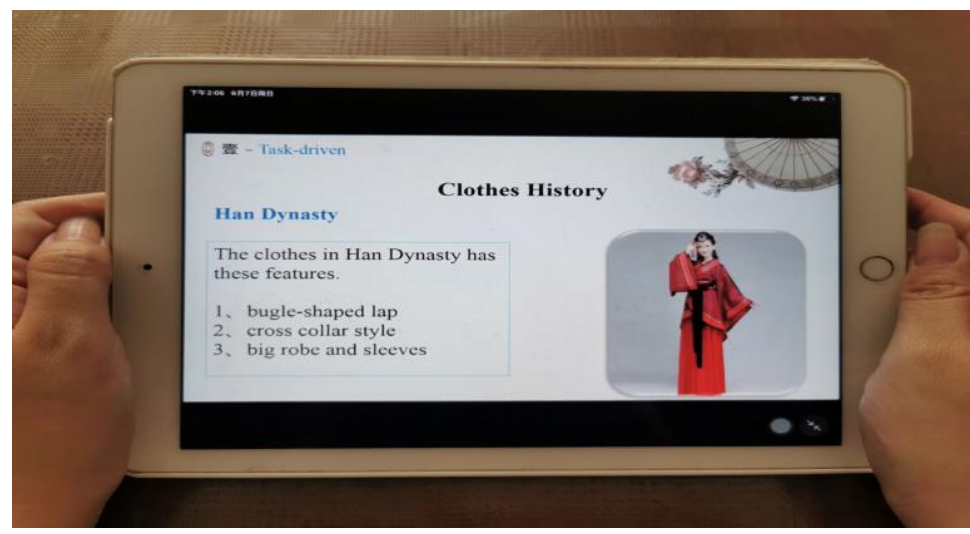

Fig. 3. Display of excellent works completed by assessment-for-learning teaching mode 


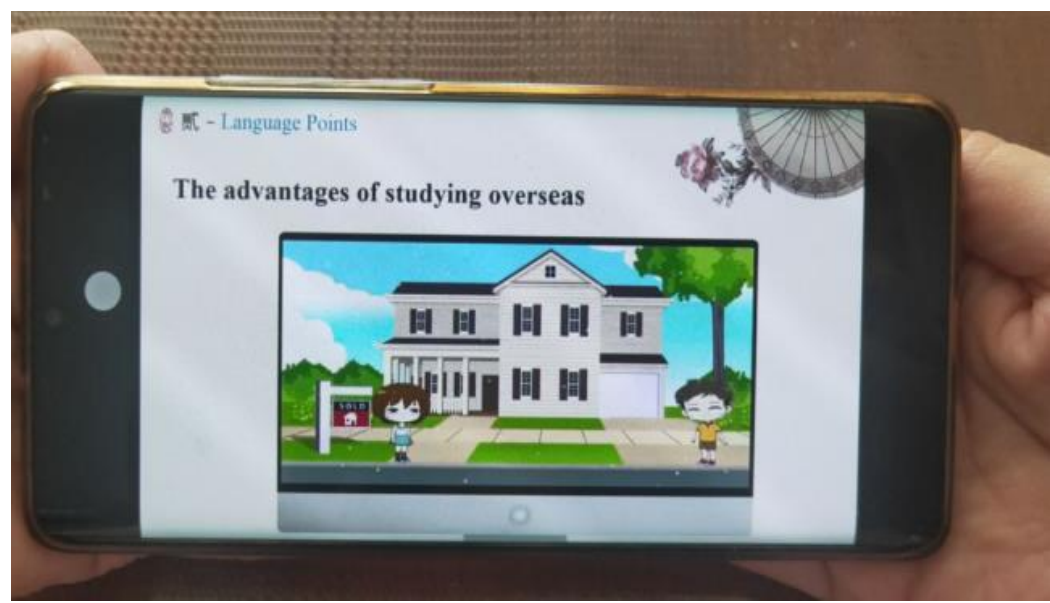

Fig. 4. Courseware independently made by students by assessment-for-learning teaching mode

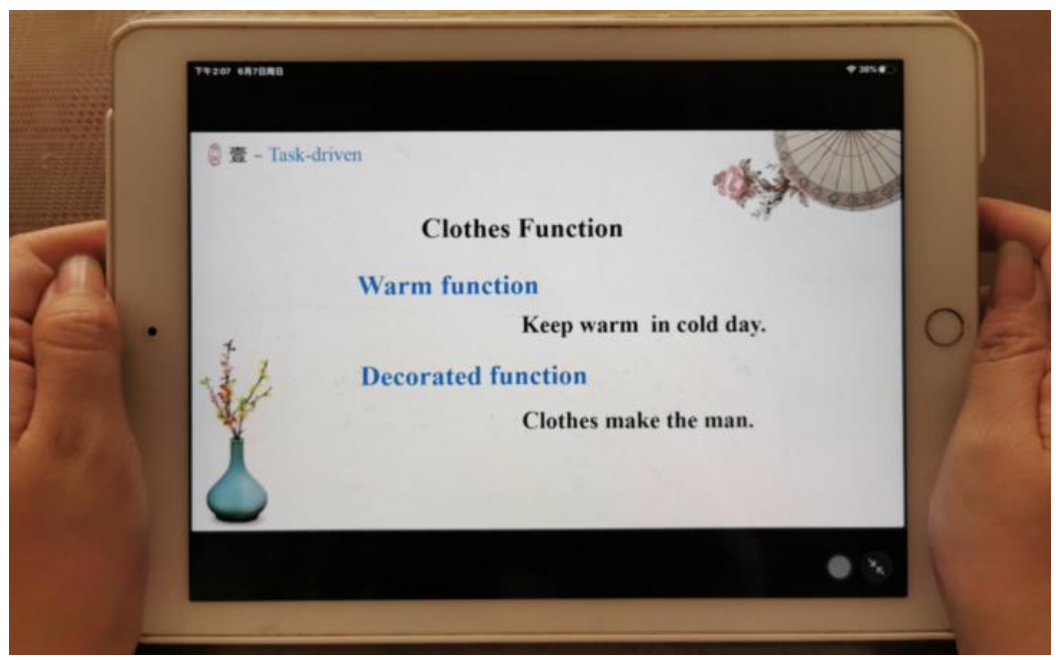

Fig. 5. Spoken English situation designed by students by assessment-for-learning teaching mode

\subsection{Learning performance evaluation system of assessment-for-learning teaching mode}

In the teaching process of college English teaching, the interaction between students and teachers and learning performance were evaluated. The data of four dimensions (degree of English learning engagement, completion degree of English learning content, degree of English learning interaction, and English learning effect) were collected through the college English teaching assistance platform of online interactive teaching method based on assessment for learning, and the learning 
performance evaluation system supported by big data was established (as shown in Table 1). In the class of college English, students' learning process and teacher's teaching process could be assessed and judged rationally, and the feedback information could be provided for teachers in time so that teachers could intervene in students in time, adjust learning attitude and promote learning method improvement.

Table 1. College English learning performance evaluation system

\begin{tabular}{|l|l|}
\hline \multicolumn{1}{|c|}{ Indicator } & \multicolumn{1}{c|}{ Evaluation content } \\
\hline $\begin{array}{l}\text { Degree of English learning } \\
\text { engagement }\end{array}$ & $\begin{array}{l}\text { Relevant video watching times before English class, assignment hand-in times } \\
\text { before class, reading times of English teaching materials, total duration of } \\
\text { viewing English teaching videos, times of logging in English class learning } \\
\text { platform, times of quiz hand-in }\end{array}$ \\
\hline $\begin{array}{l}\text { Completion degree of } \\
\text { English learning content }\end{array}$ & $\begin{array}{l}\text { Completion rate of English video learning tasks before class, completion rate of } \\
\text { English assignments before class, completion rate of quiz }\end{array}$ \\
\hline $\begin{array}{l}\text { Degree of English learning } \\
\text { interaction }\end{array}$ & $\begin{array}{l}\text { Reply times of English class brainstorming area, publishing times of drafts in } \\
\text { English class, releasing times of bullet screen posts in English class }\end{array}$ \\
\hline English learning effect & $\begin{array}{l}\text { Score of pre-class English assignments, quiz score, score of replies in English } \\
\text { discussion area, score of answers in English class }\end{array}$ \\
\hline
\end{tabular}

To further determine the key variables influencing students' learning performance, simple correlation analysis of dependent variables and students' learning performance is required. According to the results, the variables which have significant positive correlation with students' academic performance include college English performance at ordinary time, total duration of viewing English teaching videos, times of logging in English class learning platform, times of quiz hand-in, completion rate of quiz, quiz score, score of replies in English discussion area, score of answers in English class, releasing times of bullet screen posts in English class, and completion rate of drafts published in English class. Other variables with Sign value greater than 0.05 were eliminated from the initial dataset, and the 10 variables were chosen as dependent variables for further analysis. In the new variable dataset, correlation coefficients ( $r$ ) of 3 variables were greater than 0.7, indicating that the 3 variables (English performance at ordinary time, quiz score and score of answers in English class) are highly related to students' performance. In the remaining 7 variables, the correlation coefficients (r) were 0.5-0.6, demonstrating that the 7 variables are moderately related to students' performance.

In the new variable set, only 2 variables (total duration of viewing English teaching videos and score of replies in English class brainstorming area of English class) are the data of pre-class online learning activities, and the other 8 variables are the data of offline classroom learning activities. This also further proves that single online learning cannot ensure students' mastery of knowledge and that students' learning depth is not enough. Offline course is also needed to help students achieve knowledge internalization and absorption, and classroom learning plays a more important role. In other words, the blended teaching neither replaces classroom teaching with online learning, nor partially replaces face-to-face teaching, but takes the advantages of online and face-to-face teaching to improve classroom teaching, promote students' autonomous learning and improve learning effect. 
Various data of 59 students randomly chosen from English Language Department of a university were imported into SPSS 22. According to Table 2, KMO value was 0.744 , and $\mathrm{p}$ value of Bartlett Test of Sphericity was 0.000 , indicating that the factor analysis result could well explain the relations among variables. The data are suitable for principal component analysis (PCA).

Table 2. OKMO and Bartlett tests

\begin{tabular}{|l|l|c|}
\hline \multicolumn{2}{|c|}{ Kaiser-Meyer-Olkin measurement of sampling adequacy } & $\mathbf{0 . 7 4 4}$ \\
\hline \multirow{3}{*}{ Bartlett Test of Sphericity } & Approximate chi-square & 1665.725 \\
\cline { 2 - 3 } & df & 45 \\
\cline { 2 - 3 } & Sig. & 0.000 \\
\hline
\end{tabular}

During multiple linear regression, approximate linear relation among independent variables often appeared. Such phenomenon is called multicollinearity. When multicollinearity exists, the regression model established by the least square method will make the regression equation become unstable. Principal component regression is an effective method to solve multicollinearity in regression analysis.

Data standardization: Since the units of variables differed, the differences among data were also large. Thus, data standardization was conducted first. The standardized data as variables were saved on original data, distributed as zy, zx1, zx2, zx3, zx4, zx5, zx6, zx7, zx8, zx9 and zx10.

Table 3. Means and standard values of variables

\begin{tabular}{|c|c|c|c|}
\hline & N & M & SD \\
\hline $\mathrm{y}$ & 59 & 73.19 & 11.88 \\
\hline $\mathrm{x} 1$ & 59 & 69.19 & 20.98 \\
\hline $\mathrm{x} 2$ & 59 & 10.20 & 4.38 \\
\hline $\mathrm{x} 3$ & 59 & 23.20 & 4.41 \\
\hline $\mathrm{x} 4$ & 59 & 13.08 & 4.42 \\
\hline $\mathrm{x} 5$ & 59 & 0.77 & 0.26 \\
\hline $\mathrm{x} 6$ & 59 & 72.83 & 27.43 \\
\hline $\mathrm{x} 7$ & 59 & 32.71 & 9.50 \\
\hline $\mathrm{x} 8$ & 59 & 77.37 & 19.76 \\
\hline $\mathrm{x} 9$ & 59 & 0.49 & 0.68 \\
\hline $\mathrm{x} 10$ & 59 & 0.16 & 0.23 \\
\hline
\end{tabular}

Multicollinearity diagnosis: Collinearity aims to analyze the matrix $X^{\prime} X$ consisting of independent variable observation data and reflect correlation among independent variables by various indexes. Common collinearity diagnosis methods include condition number, tolerability (variance inflation factor, VIF) and characteristic root. Generally, when $\mathrm{T}<0.1$, collinearity is very serious. The tolerability of zx2, zx3, zx6 and zx10 was less than 0.1, and corresponding VIF was also large, indicating they have serious collinearity.

PCA: 3 characteristic values were $\lambda 1=6.618, \lambda 2=1.65$ and $\lambda 3=0.665$. The cumulative contribution rate of the first three characteristic values reached $89.328 \%$. 
The normalized feature vectors of the first three characteristic values $(\lambda 1=6.618$, $\lambda 2=1.65$ and $\lambda 3=0.665$ ) were:

$$
\begin{aligned}
& \varphi 3=\left(\frac{0.184}{\sqrt{\lambda_{3}}}, \frac{0.667}{\sqrt{\lambda_{3}}}, \frac{0.152}{\sqrt{\lambda_{3}}}, \frac{0.228}{\sqrt{\lambda_{3}}}, \frac{0.229}{\sqrt{\lambda_{3}}}, \frac{0.112}{\sqrt{\lambda_{3}}}, \frac{0.185}{\sqrt{\lambda_{3}}},-\frac{0.109}{\sqrt{\lambda_{3}}}, \frac{0.006}{\sqrt{\lambda_{3}}}, \frac{0.005}{\sqrt{\lambda_{3}}}\right)^{\prime} \\
& =(0.226,0.818,0.186,-0.28,-0.281,-0.137,-0.227,-0.134,0.007,0.006)^{\prime} \\
& \varphi 2=\left(-\frac{0.104}{\sqrt{\lambda_{2}}}, \frac{0.109}{\sqrt{\lambda_{2}}}, \frac{0.189}{\sqrt{\lambda_{2}}}, \frac{0.219}{\sqrt{\lambda_{2}}}, \frac{0.22}{\sqrt{\lambda_{2}}}, \frac{0.066}{\sqrt{\lambda_{2}}},-\frac{0.142}{\sqrt{\lambda_{2}}}, \frac{0.038}{\sqrt{\lambda_{2}}}, \frac{0.857}{\sqrt{\lambda_{2}}}, \frac{0.858}{\sqrt{\lambda_{2}}}\right)^{\prime} \\
& =3=\left(\frac{0.184}{\sqrt{\lambda_{3}}}, \frac{0.667}{\sqrt{\lambda_{3}}}, \frac{0.152}{\sqrt{\lambda_{3}}}, \frac{0.228}{\sqrt{\lambda_{3}}}, \frac{0.229}{\sqrt{\lambda_{3}}}, \frac{0.112}{\sqrt{\lambda_{3}}}, \frac{0.185}{\sqrt{\lambda_{3}}},-\frac{0.109}{\sqrt{\lambda_{3}}}, \frac{0.006}{\sqrt{\lambda_{3}}}, \frac{0.005}{\sqrt{\lambda_{3}}}\right)^{\prime} \\
& =(0.226,0.818,0.186,-0.28,-0.281,-0.137,-0.227,-0.134,0.007,0.006)^{\prime}
\end{aligned}
$$

The 1st, 2nd and 3rd principal components were gained as below:

$$
\begin{aligned}
& \mathrm{y}_{1}=0.375 \mathrm{z}_{x 1}+0.277 \mathrm{z}_{x 2}+0.312 \mathrm{z}_{x 3}+0.350 \mathrm{z}_{x 4}+0.350 \mathrm{z}_{x 5}+0.376 \mathrm{z}_{x 6} \\
& +0.324 \mathrm{z}_{x 7}+0.34 \mathrm{z}_{x 8}+0.198 \mathrm{z}_{x 9}+0.198 \mathrm{z}_{x 10} \\
& \mathrm{y}_{2}=-0.081 \mathrm{z}_{x 1}+0.085 \mathrm{z}_{x 2}+0.147 \mathrm{z}_{x 3}+0.170 \mathrm{z}_{x 4}+0.171 \mathrm{z}_{x 5} \\
& +0.051 \mathrm{z}_{x 6}-0.111 \mathrm{z}_{x 7}+0.03 \mathrm{z}_{x 8}+0.667 \mathrm{z}_{x 9}+0.668 \mathrm{z}_{x 10} \\
& \mathrm{y}_{3}=0.226 \mathrm{z}_{x 1}+0.818 \mathrm{z}_{x 2}+0.186 \mathrm{z}_{x 3}+0.28 \mathrm{z}_{x 4}+0.281 \mathrm{z}_{x 5} \\
& +0.137 \mathrm{z}_{x 6}+0.227 \mathrm{z}_{x 7}-0.134 \mathrm{z}_{x 8}+0.007 \mathrm{z}_{x 9}+0.006 \mathrm{z}_{x 10}
\end{aligned}
$$

Regression coefficient of principal components: The regression equation was first established for standardized dependent variable zy, the 1st principal component $\mathrm{y} 1$, the 2nd principal component y2, and the 3rd principal component y3. According to Table 6 , the estimated values of regression coefficients of the three principal components were $\beta 1=0.0287 £ \neg \beta 2=0.127 £ \neg \beta 1=0.042 £ \neg$. The constant term approximated 0 , so it could be ignored. There was no multicollinearity for principal component variables, so the regression equation of principal components was

$$
\begin{aligned}
& z_{y}=0.0287 y_{1}+0.127 y_{2}+0.042 y_{3} \\
& t=(8.36) \quad(1.842) \quad(0.387) \\
& R^{2}=0.572 \quad \operatorname{Pro}(F)=0
\end{aligned}
$$

The regression equation was significant on the while and the coefficient was significant, too.

The Expression (1) of the three principal components was substituted into Equation (2) to gain

$$
\begin{aligned}
& \mathrm{z}_{\mathrm{y}}=0.01 \mathrm{z}_{x 1}+0.053 \mathrm{z}_{x 2}+0.035 \mathrm{z}_{x 3}+0.043 \mathrm{z}_{x 4}+0.044 \mathrm{z}_{x 5} \\
& +0.023 \mathrm{z}_{x 6}+0.014 \mathrm{z}_{x 7}+0.008 \mathrm{z}_{x 8}+0.091 \mathrm{z}_{x 9}+0.091 \mathrm{z}_{x 10}
\end{aligned}
$$

According to Table 1, the expression of standardized variable was 


$$
z_{x 1}=\frac{x_{1}-69.138}{20.9834}, \cdots \cdots, z_{x 10}=\frac{x_{10}-0.1629}{0.2259}
$$

They were substituted into Equation (3) to gain the regression equation of original variable

$$
\begin{aligned}
& \mathrm{y}=0.7757+0.0005 \mathrm{x}_{1}+0.012 \mathrm{x}_{2}+0.008 \mathrm{x}_{3}+0.009 \mathrm{x}_{4}+0.168 \mathrm{x}_{5}+0.008 \mathrm{x}_{6} \\
& +0.0015 \mathrm{x}_{7}+0.0004 \mathrm{x}_{8}+0.134 \mathrm{x}_{9}+0.401 \mathrm{x}_{10}
\end{aligned}
$$

\section{Teaching Example and Effect}

\subsection{Teaching example}

At present, formal evaluation is popular, but college teachers and students are still influenced by exam-oriented education, and it is very difficult to give play to the positive effect of formal evaluation to promote students' study. The efficiency of college English teaching is generally low, and the teaching effect is poor. Therefore, some scholars proposed to highlight the evaluation of students' learning process assessment for learning. Such mode regarded promotion of students' learning evaluation as the primary goal, and students' learning process was guided by teachers. The interactive teaching approach was integrated in English course teaching, and a learning performance evaluation system suitable for the course was constructed. The purpose was to understand students' English knowledge and level in advance, analyze characteristics of students with poor English knowledge, pay more attention to those with poor performance and weak knowledge level in the early stage of English course, provide targeted remedial measures and thus guarantee learning effect of the new teaching mode in college English course. To sum up, assessment for learning is a teacher-student cooperative teaching mode in which students play the leading role. The teacher guided students to the point through students' online preview, and students' ability kept strengthening and enthusiasm for English study continued to improve. The assessment-for-learning teaching mode for college English course was constructed as shown in Fig.6. 

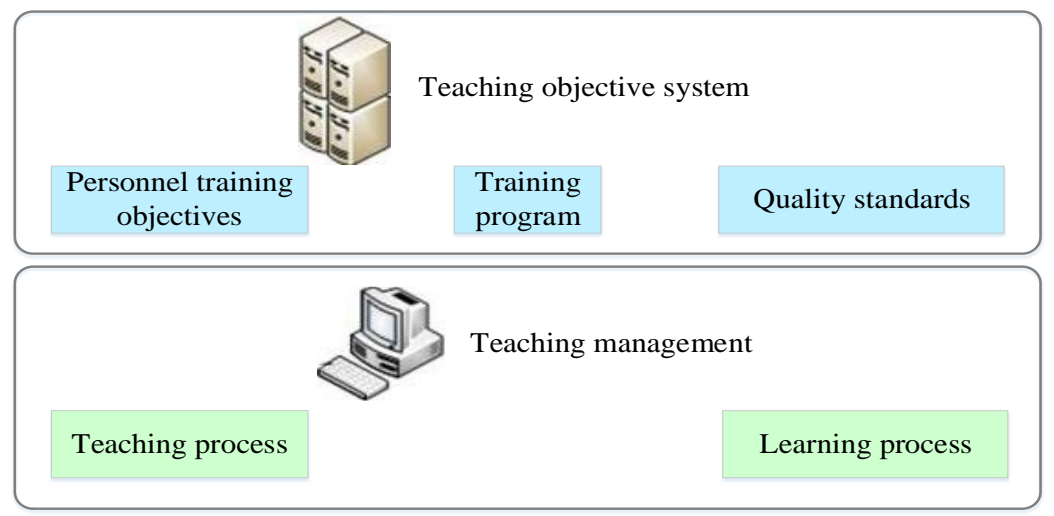

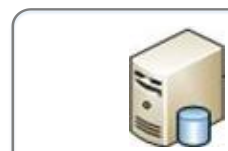

Intelligent teaching objectives

Learning Steering Committee

Learning Steering Committee

Teaching Steering

Committee

Teaching management office

Question bank
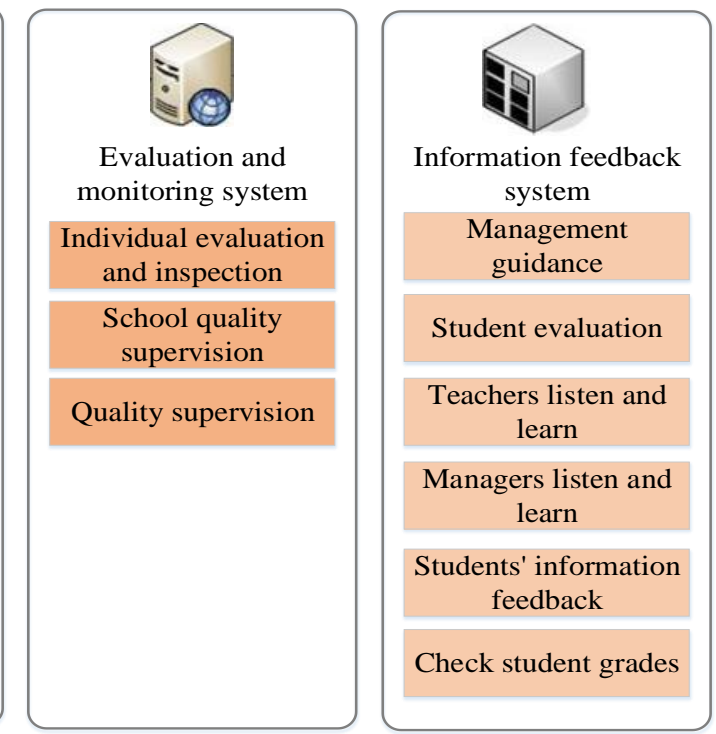

Fig. 6. Construction of assessment-for-learning teaching mode based on interactive teaching approach

\subsection{Teaching effect}

In this study, the assessment-for-learning teaching mode for college English was constructed. Based on the above analysis, the research results of control group and experimental group are shown in Table 6. Either group included 40 students. All students were freshmen. Before grouping, English performance of both groups was of no difference. All subjects were informed, and agreed to participate in this study. The experimental period lasted for 12 weeks, from March to May 2020. One lesson was given per week, and two lessons were given every time $(80 \mathrm{~min})$. The experimental group was given "assessment-for-learning" teaching method combined with interactive teaching and case library method. The traditional English teaching method 
was adopted for the control group, that is, the teacher gave lessons, and students learned. After the experiment ended, the usual performance and final examination results of both groups were compared and analyzed, as shown in Table 4.

Table 4. Comparison of usual English performance and final English theory examination results between the two groups

\begin{tabular}{|l|c|c|}
\hline \multicolumn{1}{|c|}{ Item } & Usual English performance & Final English theory examination results \\
\hline Control group $(\mathrm{n}=40)$ & $92.70 \pm_{1.95}$ & $84.08 \pm_{4.46}$ \\
\hline Experimental group $(\mathrm{n}=40)$ & $95.03 \pm_{2.12}$ & $89.18 \pm_{3.96}$ \\
\hline $\mathrm{t}$ value & -5.11 & -5.41 \\
\hline P value & $<0.001$ & $<0.001$ \\
\hline
\end{tabular}

It can be seen from Table 6 that, Usual English performance and final English theory examination results of experimental group were significantly higher than those of control group, and the difference was statistically significant. The results of this study show that, College English course based on "assessment-for-learning" teaching mode and combined with the interactive teaching approach could help students improve their learning interest, results and effect. The reasons are as below: firstly, the teaching mode could motivate students' learning motivation and help students enhance learning confidence and enthusiasm through establishing standard consciousness. For example, during forming the evaluation standards of "assessment for learning", the teacher should develop detailed evaluation criteria at the beginning of the semester or the initial stage of project implementation, and guide students to define the learning goals and striving direction. After students learn about the evaluation standards in detail, their learning initiative will improve. Meanwhile, selfevaluation contributes to students' timely introspection and thus keeping improving their learning methods. Secondly, the teaching mode could effectively improve the relationship between teachers and students. The teacher should assess students' knowledge learning, guide students for introspection and comment student evaluation results during assessment for learning and students' independent completion of case library learning. Moreover, the teaching mode is beneficial for teachers to update teaching ideas and turn to attaching importance to stimulating students' learning enthusiasm through assessment from paying attention to "teaching". Such teaching mode urges teachers to innovate in teaching methods and reach the teaching objective of improving students' learning initiative and learning effect. In teaching, teachers not just need apply interactive teaching and case library technology for course design to make classroom teaching more vivid and teaching effect more outstanding, but also should learn relevant evaluation strategies in advance so as to guide students for objective and effective mutual evaluation and self-evaluation. 


\section{Conclusion}

This study on college English course was based on "assessment-for-learning" teaching mode. The interactive teaching approach was integrated in English course teaching, and a learning performance evaluation system suitable for the course mode was constructed. The application results of the teaching mode show that in college English course, assessment-for-learning teaching mode based on interactive teaching approach is very necessary and feasible.

1. Such teaching mode contributes to improving teaching effect, lays a foundation for boosting practical teaching quality and can practically enhance the teaching quality of colleges for training applied talents.

2. In English teaching, it is very necessary to understand students' existing English knowledge level in advance, analyze characteristics of students with poor English knowledge, pay more attention to those with poor performance and weak knowledge level in the early stage of English course and provide targeted remedial measures. The teaching effect of the new teaching mode can be really guaranteed only when the teacher carries out corresponding teaching according to learning level of different students.

3. In the teaching environment where information technology develops at a high speed, English teachers should comply with the development of teaching reform, mainly cultivate students' English application ability, and strive to improve the assessment and evaluation mechanism consistent with information technology, thus enhancing students' social competitiveness and meeting social diversified demands.

\section{$6 \quad$ References}

[1] Sheng, Z. Infiltration and application cases of scientific methods in junior high school physics teaching. Zhongxue Wuli, 2016, vol. 34(5), pp. 21-22.

[2] Flohr, S. Teaching Literature: Language and Cultural Awareness Using the Example of "Hills Like White Elephants". journal of northwest a \& f university, 2012, vol. 40(3), pp. 7-12.

[3] Chen, Y.W. On the cultivation of College Students' English language application ability. Journal of Heilongjiang Institute of Teacher Development, 2012, vol. 31(12), pp. 188-189.

[4] Jemma, S. Learner writing strategies of Seychellois ESL (English as a second language) secondary school students: A sociocultural theory perspective. Learning Culture \& Social Interaction, 2016, vol. 8, pp. 1-11. https://doi.org/10.1016/j.lcsi.2015.11.002

[5] Celce-Murcia, M., Brinton, D. M. , \& Goodwin, J. M. Teaching pronunciation : a reference for teachers of english to speakers of other languages. Tesol Quarterly, 2012, vol. 32(2), pp. 783-784. https://doi.org/10.2307/3588013

[6] Zhong, J.K. Private universities and community colleges in the United States. Modern City, 2014, vol. 9(1), pp. 55-58.

[7] Suemitsu, A., Dang, J., Ito, T. , \& Tiede, M. . (2015). A real-time articulatory visual feedback approach with target presentation for second language pronunciation learning. 
Journal of the Acoustical Society of America, vol. 138(4), EL382. https://doi.org/10.1121/ 1.4931827

[8] Muhanna, W. Using Online Games for Teaching English Vocabulary For Jordanian Students Learning English As A Foreign Language. Journal of College Teaching \& Learning, 2012, vol. 9(3), pp. 235-244. https://doi.org/10.19030/tlc.v9i3.7178

[9] Gimenez, T., \& Ramos, S. G. M. Planning and implementing an online course as a teaching practicum activity in English language teaching. Ilha Do Desterro, 2014, vol. 94(66), pp. 101-132.

[10] Sun, H. The Learning Method of Peer Review in College English Writing Course. International Journal of Emerging Technologies in Learning, 2020, vol. 15(5), pp. 156170. https://doi.org/10.3991/ijet.v15i05.13775

[11] Sun, H. A SPOC Teaching Mode of College English Translation Based on "Rain Classroom". International Journal of Emerging Technologies in Learning, 2019, vol. 14(17), pp. 182-193. https://doi.org/10.3991/ijet.v14i17.11206

[12] Ling, S.Z. Research on the application of group cooperative teaching in the introduction of advanced English cultural background. China Electric Power Education, 2012, vol. 39(13), pp. 149-150.

[13] Du, H.L. Application and Practice of Double-Subject Interactive Teaching Mode in the English Newspaper Reading Teaching. Journal of Qiqihar Junior Teachers' College, 2012. vol. 29(4), pp. 143-145.

\section{$7 \quad$ Authors}

Rui Sun is an associate professor in the Heze Medical College, Heze, China (abc7320938@126.com).

Huihui Zhang is a Lecturer in the Heze Medical College, Heze, China (1956989462@qq.com).

Jing Li is a Lecturer in the Heze University, Heze, China (270903695@qq.com).

Jing Zhao is an associate professor in the Guizhou Education University, Guiyang, China (42060602@qq.com).

Peipei Dong is a Lecturer in the Hebei GEO University, Shijiazhuang, China (120650334@qq.com).

Article submitted 2020-08-24. Resubmitted --. Final acceptance 2020-09-07. Final version published as submitted by the authors. 